\title{
Yemlerine Farklı ve Artan Miktarlarda Doğal Zeolit (Klinoptilolit) Katılan Etlik Piliçlerin Besi Performanslarinin Belirlenmesi
}

\author{
Beyhan YETER ${ }^{1} \mathscr{P}$ (D), Gülin GÖKÇE ${ }^{2}$ (D) \\ ${ }^{1}$ Kahramanmaraş Sütçü İmam Üniv. Ziraat Fak. Zootekni Böl., Kahramanmaraş, ${ }^{2}$ Kahramanmaraş Sütçü İmam Üniv. Fen \\ Bilimleri Enstitüsü Zootekni Ana Bilim Dalı., Kahramanmaraş \\ $\bowtie$ : byeter@ksu.edu.tr
}

\section{ÖZET}

$\mathrm{Bu}$ çalışma, farklı düzeylerde ve artan oranlarda zeolit içeren yemin, etlik civcivlerin besi performansina etkilerini incelemek amaciyla, KSÜ HAYMER'de bulunan etlik civciv kümesinde, tesadüf parseller deneme deseninde 3 grup ve her grup için 3 tekerrürden oluşmuştur. Her tekerrüre karışık cinsiyette 40 adet Ross 308 civciv 4'er m²'lik alana konulmuştur. Denemede standart 4 çeşit ticari yem 1-10, 11-21, 22-35 ve 36-42. günler arasında kullanılmıştır. Kontrol grubuna zeolit ilavesi yapılmazken, muamele 1 grubundaki hayvanlara \% 0.5, 0.75, 1, 1.25 oranlarında, muamele 2 grubundaki hayvanlara \%1, 1.5, 2, 2.5 oranlarında zeolit sirası ile 1-14, 15-21, 22-35 ve 36-42 günlerde ilave edilmiştir. Denemeye alınan hayvanların tamamı haftalık olarak tartılmış, ortalama canlı ağırlıkları ve yem dönüşüm oranları belirlenmiştir. Deneme sonunda, 4. haftada canlı ağırlık bakımından gruplar arasında istatistikî bir fark görülmüştür $(\mathrm{P}<0.05)$. Ancak deneme sonunda (6. hafta) canlı ağırlık bakımından gruplar arasında istatistikî olarak bir fark görülmemiştir( $(\mathrm{P}>0.05)$. Grup 1, grup 2 ve kontrol gruplarındaki piliçlerin 6 . hafta sonundaki canlı ağırlıkları sırası ile 2620.0, 2621.0 ve $2619.7 \mathrm{~g}$ olarak bulunmuştur. Yem dönüşüm oranı (FCR) bakımından da gruplar arasında tüm haftalarda istatistikî bir fark bulunamamıştır $(\mathrm{P}>0.05)$. Muamele ve kontrol gruplarındaki hayvanların 6. hafta sonundaki yem dönüşüm oranları sırası ile $1.663,1.640$ ve 1.637 olarak bulunmuştur. Sonuç olarak; etlik piliç yetiştiriciliğinde yemlerine farklı düzeylerde ve artan oranlarda ilave edilen zeolit canlı ağırlıkta bir artış olmadığı ve yem dönüşüm oranı değerlerini değiştirmediği belirlenmiştir.
DOI:10.18016/ksudobil.397313

Makale Tarihçesi

Geliş Tarihi: 21.02.2018

Kabul Tarihi: 06.04.2018

\author{
Anahtar Kelimeler \\ Etlik Piliç, \\ Besi Performansı, \\ Zeolit
}

Araştırma Makalesi

\section{Determination of Growth Performances with Addition of Increased Concentraton Zeolite (Clinoptylolide) in Broiler}

\section{ABSTRACT}

This study was conducted to investigate the effects of zeolite containing feed on broiler chickens. The experiment conducted in three groups with three replications for each group at KSÜ HAYMER and experiment set up in a randomized parcel trial design. Each replicate contained 40 Ross-308 chicks (male and female) and placed in 4 square meter area. Four different commercial diets were used for 1-10, 11-21, 22-35 and 36-42 days of growth. Zeolite was not added for control group but treatment group I animals were fed on diets including $1,1.5,2$ and $2.5 \%$ zeolite. Treatment group II were fed on diets prepared with $1,0.75,1,1.25 \%$ zeolite inclusions. All animals were weighed weekly, average live weights and feed conversion rates were determined. There was a statistically significant difference between live weight groups at $4^{\text {th }}$ week $(\mathrm{P}<0.05)$. However, there was no significant difference in live
Article History

Received : 21.02.2018

Accepted : 06.04.2018
Keywords
Broiler Chickens,
Growth Performance,
Zeolite

Research Article 
weight between the groups at the end of $6^{\text {th }}$ week of the experiment ( $>>0.05)$. Body weights of the chicks in group 1, group 2 and control group were found $2620.0,2621.0$ and $2619.7 \mathrm{~g}$, respectively. In terms of feed conversion ratio (FCR), no significant difference was found between groups in all weeks $(\mathrm{P}>0.05)$. At the end of experiment, feed conversion ratios for treatment and control groups were calculated as 1.663, 1.640 and 1.637, respectively. I was concluded that growth performance of broiler chicks was not affected by dietary zeolite inclusions.

To cite : Yeter B, Gökçe G 2018. Yemlerine Farklı ve Artan Miktarlarda Doğal Zeolit (Klinoptilolit) Katılan Etlik Piliçlerin Besi Performanslarının Belirlenmesi. KSÜ Tar Doğa Derg 21(5) : 745-750, DOI : 10.18016/ksudobil.397313

\section{GIRISS}

Ülkemizde tavuk eti sektörünün çok önemli bir yeri vardır. Üretim miktarı her yıl artarak devam etmekte ve daha da artacağı ileri sürülmektedir. Dünya tavuk eti üretiminde ilk üç sırayı ABD, Çin, Brezilya alırken Türkiye ilk on içinde yer almaktadır(Camcı ve ark., 2016). Günümüzde dünya nüfusunun artışıyla beraber besin ihtiyacının artması en önemli sorunlardan biridir. Gelişmiş ülkelerle yeni gelişmekte olan ülkeler arasında bir karşılaştırma yapıldığında gelişmekte olan ülkelerin beslenmeleri öncelikle karbonhidratça zengin bitkisel kökenli yiyeceklere dayanırken, gelişmiş ülkelerin özellikle beslenmelerinde hayvansal kökenli yiyeceklerin çok daha önemli bir yere sahip olduğu görülmektedir. İnsan vücudunun hayati gereksinimleri arasinda yer alan esansiyel aminoasitleri en dengeli biçimde içeren hayvansal kökenli besinlerin başında et gelmektedir. Zihinsel gelişmeyi hızlandırmakta ve toplumların ilerlemesinde önemli rol oynamaktadır. Bu sebeple, günümüzde toplumların gelişmişlik seviyeleri, tükettikleri hayvansal kökenli yiyeceklerin miktarı ile ölçülmektedir(Şengonca, 1998). Tavuk etinin besin değerinin yüksek olması, az zamanda çok üretim gerçekleştirilebilmesi, piliçlerin yem değerlendirmesinin iyi olması ile ucuz beyaz et proteini sağlanabilmektedir. Bu sebeple tavukçuluk, hayvansal üretim içerisinde çok önemli bir yere sahiptir(Bayaner, 1999). Etlik piliçlerde yoğun yetiştirme şartlarının artması ve daha fazla ürün alabilme çabalarından dolayı çok farklı yem katkı maddelerinin bilinçsiz bir şekilde kullanması ile sağlık kriterleri arka planda kalmıştır, son yıllarda ise hayvanın sağlığını etkilemeyecek ancak verimi artırabilecek yem katkı maddelerinin kullanılabilirliği üzerinde çalışmalar artmıştır. Bu alanda kullanılan mineral kaynaklardan biride zeolittir(Demirel ve ark., 2010). Zeolitlerin milyonlarca sene evvel volkanik küllerin ıslak ortamda değişime uğraması ile alkali ve toprak alkalilerin hidratlı doğal silikatlarından oluşan bir mineral grubu olduğu bildirilmektedir(Bilgin ve Koç, 2013). Zeolitler, yapılarında silikon, alüminyum ve oksijen ihtiva eden sulu alüminosilikat mineralleridir. Tabiatta volkanik tüf ve tuzlu suyun reaksiyonu ile oluşurlar. Zeolitler, pozitif yüklü olan iyonları atomları ve diğer bileşenleri absorbe eden ve bulundukları ortamdan uzaklaştıran moleküler bir elek veya filtre gibi davranırlar. Yapıları kil minerallerine benzemekte ve tabakalı bir yapıya sahiptirler. Ayrıca birbirine kanallarla bağlı olan, sert ve peteğe benzer üç boyutlu kristal bir yapıları vardır(Anonim, 2016). Doğal klinoptilolit (bir zeolit) yüksek absorbsiyon kapasitesine sahip olup en çok tercih edilir. Kimyasal filtre olarak, gıda ve yem katkısı olarak ayrıca koku ve gaz tutucu olarak kullanılabilmektedir. $\mathrm{Bu}$ özelliklerini, yapılarında bulunan çok miktarda gözenekler, yüksek sıcaklı̆̆a dayanıklılık ve nötr bir yapıda olmasından kazanır. Zeolit rezervleri 1950'lerden sonra bilinmeye başlamıştır. Dünyada zeolit tüketiminin yılda yaklaşık 750.000 ton olduğu, bu tüketimin \%70'i deterjanlarda, \%10'u katalizör ve adsorban üretiminde, \%8'i desikant (nem çekici) üretiminde ve \%12'si de diğer alanlarda olduğu bildirilmiştir(Köktürk, 1995). Zeolitlerin varlığı ülkemizde ilk olarak 1976 yılında GöynükGölpazarı bölgesinde tespit edilmiştir (Orhun, 1997). Türkiye'de, yaklaşlk 50 milyar ton zeolit rezervi olduğu bilinmektedir. Maden Tetkik Arama Enstitüsü'nün yaptığı araştırmalara göre GördesManisa'da klinoptilolit yatakları 2 milyar ton görünür rezerv olduğunu bildirmektedir. İçeriğinde bulunan yüksek klinoptilolit oranı ve istenmeyen maddelerin azlığı, bu bölgedeki zeolit yataklarını kaliteli hale getirmektedir(Mol, 2001). Doğal zeolitler hayvan beslemenin dışında, toprak kirliliğinin kontrolü, gübreleme, toprak hazırlanması, zirai mücadele, atık suların baca gazlarının petrol sızıntı atıklarının temizlenmesi, termik santrallerinde, doğal gazların saflaştırılmasında, petrol ürünlerinin üretiminde, kâğıt endüstrisinde ve deterjan üretiminde de yaygın şekilde kullanılmaktadır(Özaydın, 2005). Zeolitlerin hayvan beslemede kullanımı 1965 yıllarında başlamış, özellikle besi hayvanlarında kullanılabilirliği konusunda yapılan araştırmalarda, \%1.5-15 arasında değişen düzeylerde karma yemlere katılabileceği, bu oranların hayvan sağlığını bozmadığı, aksine canlı ağırlıklarda iyileşme sağladığı belirtilmiştir. Besi hayvanlarında genellikle mordenit ve klinoptilolit çeşitleri kullanılmaktadır. Yemlere katılarak 
kullanılan zeolitlerin \%75-85 oranında klinoptilolit içermesi gerektiği vurgulanmıştır ve zeolitlerin diğer yem içerikleriyle (vitamin, antibiyotik, iz elementler veya fosfatlar) interaksiyona girmedikleri belirtilmiştir(Pond ve ark., 1988). Kanatlı hayvan yetiştiriciliğinde zeolitin farklı kullanım alanlarına sahip olduğu görülmektedir. Kümeslerde altlığa karıştırılarak ya da yem katkı maddesi olarak hem yumurtacı hem de etlik tavuklarda ilgili çalışmalar mevcuttur. Yapılan birçok çalışmada, zeolitin kanatlı hayvanlar üzerinde farklı etkilerinin bulunduğu belirlenmiştir. Zeolitin diğer minerallerden farklı bazı özelliklerinden dolayı farklı alanlarda kullanım olanakları araştırılırken, üzerinde durulan ve merak konusu olan yumurta kabuk kalitesini artırmak amacı ile yapılan çalışmalardır. Bazı araştırıcılar, çalışmalarında yeme zeolit katmanın yumurtacı tavukların yumurta verimini etkilemediğini (Roland ve ark., 1985; Roland, 1988; Keshavarz ve McCormick, 1991; Altan ve ark., 1998; Öztürk ve ark., 1998; Balevi ve ark., 1999), bazı araştırmacılar ise yeme doğal zeolit ilave edilmesinin yumurta verimini artırdığı yönünde etki gösterdiğini bildirmişlerdir (Merabishvilli ve ark., 1980; Yalçın ve ark., 1987). Bazı çalışmalarda ise zeolitli yemin yumurta randımanını iyileştirmediği gibi hatta olumsuz yönde etkilediğini bildirilmişlerdir (Nakaue ve Koelliker, 1981; Miles ve ark., 1986; Fethiere ve ark., 1990; Roland ve ark., 1991). Ayrıca klinoptilolit sığır, domuz, at ve tavuk yemlerine katkı maddesi olarak konulmaktadır. Dışkı ve atıklardaki toksinleri absorbe eder, hayvanlarm besin sindirimine yardımc1 olur. Benzer deneyler insan yiyecekleri üzerinde de test edilmektedir(Ata, 2003). Oğuz ve ark. (2002) etlik civciv yemine \% 1.5 ve 2.5 klinoptilolit uygulamasinin aflatoksin zararlarina azaltmada yardımcı olabileceğini belirtmektedir. Her zeolitin aynı etkiyi göstermediği, bazı zeolitlerin etkisi gözlenmezken bazı zeolitlerin yem dönüşüm oranlarını $\%$ 2'ye kadar olumlu etkilediği, ancak ortaya çıkan bu etkinin nasıl çalıştığının kesin olarak bilinmemesine karşın zeolitin azot içeren bileşikleri bağlayabildiği veya iyon değişim özelliği ile alakalı olabileceğini ayrıca bazı aminoasitlerin azot içeriğini absorbe ederek aminoasitleri stabil hale getirebileceği, böylece birim verim için gereken enerji miktarını azalttığ ayrıca da kalsiyumdan yararlanmanın arttığ 1 bildirilmiştir(Quarles, 1985; Watkins ve ark., 1989).

\section{MATERYAL ve METOT}

$\mathrm{Bu}$ çalışma, Kahramanmaraş Sütçü İmam Üniversitesi Hayvansal Üretim Uygulama ve Araştırma Merkezi (HAYMER)'de bulunan kapalı sistem etlik piliç kümesinde yapılmıştır. Çalışmanın yapıldığı kümeste havalandırma klape fan ve petlerle sağlanmıştır. Temel hava ihtiyacı minimum fan ile sağlanmış, hayvanların büyümesiyle 15 . günden sonra kümes içi sıcaklık yükseldikçe geçiş havalandırması ve tünel havalandırma devreye girmeye başlamıştır.
Hayvan materyali olarak 48 haftalık yaşlı Ross 308 hattı etlik damızlık sürünün civcivleri kullanılmıştır. Çalışma tesadüf parseller deneme deseninde, her grup için 3 tekerrür, toplam 9 bölmeden oluşturulmuş, her tekerrüre 40 adet karışı cinsiyette civcivler rastgele ve tamamı tartılıp ortalama canlı ağırlıkları tespit edilerek yerleştirilmiştir. Deneme grubu tekerrürlerine koyulan civciv ortalama canlı ağırlıkları 1. grup için $44.6,44.5 \mathrm{~g}$ ve $44.6 \mathrm{~g}$ ortalaması 44.6 g. 2. grup $44.5,44.5$ ve $44.5 \mathrm{~g}$ ortalamasi $44.5 \mathrm{~g}$ kontrol grubu $44.7,44.8$ ve $44.8 \mathrm{~g}$ ve ortalaması $44.8 \mathrm{~g}$ olarak bulunmuştur. Her bölme 2x2 m olup taban alanı $4 \mathrm{~m}^{2}$ den oluşturulmuştur. Altlık olarak, ticari bir firmanın ürettiği kâğıt fabrikası atıklarından geri dönüşüm ile elde edilmiş bir ürün kullanılmış, metrekareye $4.5 \mathrm{~kg}$ altlık materyali kullanılmıştır. Kümesin isitılması infra-red elektrikli isitıcılar ile sağlanmıştır. Elektrikli ısıtıcılar radyan benzeri aşağı yöne bakar pozisyonda takılmış, civcivler isitıcıların altına yaklaşıp uzaklaşarak istedikleri sıcakta kalmalarına imkân verilmiştir. İlk günden itibaren tasarruflu beyaz renkli 11 watt'lık ampuller ile 1 saat karanlık 23 saat aydınlık uygulaması yapılmıştır. Her iki kümeste de 1şık şiddeti 18 lüx olarak ölçülmüştür. 6. gün Newcasttle (B1) ve 12. gün Gumboro aşıları içme suları ile uygulanmıştır. Aşılar ana depo yanında bulunan 60 litrelik aşı-ilaç deposu kullanılarak nipel suluk sisteminden içme suyu ile uygulanmıştır. Yetiştirme dönemi boyunca herhangi bir sağlık problemi yaşanmamış ve herhangi bir ilaç-antibiyotik kullanılmamıştır. Suluk olarak ilk günden itibaren nipel sulama sistemi kullanılmıştır. Her tekerrürde, 4.4 adet piliç başına 1 adet nipel suluk toplam 9 adet nipel suluk kullanılmıştır. Deneme başlangıcında her tekerrür için 1 adet civciv yer yemliği ile yemleme yapılmış, 3. günden itibaren yemlik tabaklarına da yem koyulmaya başlanmıştır. 8. günden sonra yer yemlikleri tamamen kaldırılmıştır. Grupların yemlerine ilk günden itibaren Çizelge 1'deki programda zeolit ilave edilmiştir.

Çizelge 1. Deneme dizaynı

\begin{tabular}{|c|c|c|c|}
\hline \multicolumn{4}{|c|}{ Gruplar } \\
\hline Günler & 1 (Kontrol \%) & 2 (Zeolit \%) & 3 (Zeolit \%) \\
\hline $1-14$ & 0 & 0.5 & 1 \\
\hline $15-21$ & 0 & 0.75 & 1.5 \\
\hline $22-35$ & 0 & 1 & 2 \\
\hline $35-42$ & 0 & 1.25 & 2.5 \\
\hline
\end{tabular}

$\mathrm{Bu}$ çalışmada kullanılan zeolit materyali tarımsal amaçlı olarak kullanılan klinoptilolit türü ManisaGördes orijinli Gördes zeolit tarım ürünleri AŞ. Firmasından temin edilmiştir. Yemler 10'ar kg olarak tartılmış, bir muşamba üzerine $2-3 \mathrm{~cm}$ kalınlığında serilen yem üzerine zeolit homojen olarak serpilerek karıştırılmıştır. Yem ile zeolitin birbirinden ayrışarak zeolitin altta kalma ihtimaline karşı yemliklerdeki yemin tamamının bitirilmesi ile yeni yem verilmiştir. 
Hayvanların haftasının son günlerinde yemliklerde kalan yem tartılarak haftanin toplam yem tüketiminden düşülmüştür. Civciv yer yemlikleri ile denemeye başlanmış ve üçüncü günden sonra normal yemliklere de yem koyulmaya başlanarak yedinci günde yer yemlikleri kaldırılmıştır. Her tekerrür için 1 adet yer yemliği ve 3 adet spiral yemlik tabağ kullanılmıştır. Yemleme her tekerrür için tartılarak elle yapılmıştır. Denemede etlik civcivler için üretilen standart ticari 4 çeşit yem kullanılmıştır. Bu 4 çeşit yemin enerji ve ham protein oranları Çizelge 2'de gösterilmiştir. İlk 2 çeşit yem granül, 3 ve 4 . çeşit yemler pelet olarak kullanılmıştır.
Haftalık canlı ağırlık tartımları her haftanın sonuncu günü öğleden sonra yapılmıştır. Her hafta her tekerrürün tamamı toplu tartım yapılarak ortalaması alınmıştır. Son hafta (42. gün) ise 10-12 saat önceden yemleri bitmiş ve hayvanların tamamı tek tek tartım yapılmıştır. Yapılan çalışmada grupların canlı ağırlıkları ve yem dönüşüm oranlarına ilişkin istatistik analiz için gruplar arası varyans analizi ve farklılığın kontrolü içinde Tukey testi uygulanmıştır (SAS Institute 1994). Çizelgelerde ortalamalar, standart hatalar ve önem seviyeleri verilmiştir.

Çizelge 2. Etlik civciv yemlerinin ham protein ve metabolik enerji değerleri

\begin{tabular}{|l|c|c|c|}
\hline & Yemleme zamanı (günler) & HP (\%) & Metabolik Enerji Kcal/Kg \\
\hline Etlik civciv başlangıç yemi & $0-10$ & 24 & 3200 \\
\hline Etlik civciv yemi & $11-20$ & 23 & 3200 \\
\hline Etlik piliç yemi & $21-35$ & 21 & 3200 \\
\hline Etlik piliç kesim öncesi yemi & $36-42$ & 19 & 3200 \\
\hline
\end{tabular}

\section{BULGULAR ve TARTIŞMA}

Canlı ağırlık bakımından zeolit uygulaması bakımından 2. 3. ve 6 . haftalar arasında istatistikî olarak herhangi bir farklılık bulunmamıştır $(\mathrm{P}>0.05)$. 4. Haftada canlı ağırlık bakımından zeolit uygulamaları arasında farklılık tespit edilmiştir $(\mathrm{P}<0.05)$. Beşinci haftada ise uygulamalar arasındaki farklılık \%10 önem düzeyinde önemli bulunmuştur $(\mathrm{P}<0.10)$. Dördüncü hafta ortalamaları, Tukey çoklu karşılaştırma testine göre karşılaştırıldığında iki faklı grup oluşmuş, en yüksek ortalama kontrol grubu (1430.7 g), en düşük ortalamanın ise \%1 zeolitile başlanan (1310.3 g) gruptan sağlandığı görülmüştür $(\mathrm{P}<0.05)$. Beşinci haftada ise Tukey çoklu karşılaştırma sonuçlarına göre yine iki grup oluşmuş dördüncü haftada olduğu gibi en yüksek (\%0) kontrol grubu $(2058.4 \mathrm{~g})$ en düşük ise yine. $\% 1$ zeolit ile başlanan bu haftada \%2 zeolit verilen grup (1931.0 g) olduğu görülmüştür. Çizelge 3'de haftalara göre zeolit uygulamasına ait canlı ağırlıkları ve ortalama hataları Tukey çoklu karşılaştırma sonuçları verilmiştir.

Yapılan çalışmalarda ortak bir sonuca varılamamıştır. Fisinin ve ark. (1985) etlik piliç yemlerine \% 5 düzeyinde klinoptilolit ilavesinin canlı ağırlıkta iyileşmeler meydana getirdiğini ifade ederken, Eleroğlu ve ark. (2011) 240 etlik piliçler üzerinde yaptıkları bir çalışmada grupların yemlerine sırasıyla $\% 0,1,3$ ve 5 oranında doğal klinoptilolit katmışlar ve bu çalışmada etlik piliçlerin ortalama canlı ağırlıkları arasında önemli bir farklılık bulamadıklarını bildirmişlerdir. Yine aynı araştırıcının bulunduğu başka bir çalışmalarında (Eleroğlu ve Yalçın, 2005) etlik piliçlerin bu kez altlığına zeolit karıştırılmasının kümes içi çevre şartlarını iyileştirdiğini ve bunun yansıması olarak ta canlı ağırlık artışlarında bir farklılığın oluştuğunu bildirmişlerdir. Benzer bir yaklaşımı Suchy ve ark. (2006) yaptıkları çalışmada elde etmişler, broyler yemlerine $\% 1$ ve 2 düzeylerinde klinoptilolit katmışlar, deneme sonunda piliçlerin canlı ağırlıkları üzerine olumlu etki ortaya çıktığını bunun sebebinin ise deneme kümesindeki amonyağın \%30 oranında azalttığından kaynaklandığını ifade etmişlerdir. Bozkurt ve ark. (1998) yaptıkları bir çalışmada etlik civciv yemlerine sırasıyla. \%0, $1,1.5$ ve 2 oranında zeolit ilave etmişler ve çalışmanın sonunda $\% 1$ zeolit katılan grupta canlı ağırlık artışının en iyi sonuç verdiğini bildirmişlerdir. Karelina (1985), Irtysh ırkı civcivlerin bir kısmını \% 5 düzeyinde klinoptilolit içeren bir rasyonla, bir kısmını ise sadece bazal rasyonla yemlemiştir. Deneme sonunda canlı ağırlığın bazal rasyonla beslenenlere oranlar $65 \mathrm{~g}$ artırdığ sonucuna varmışlardır. Diğer taraftan, Waldroup ve ark. (1985) rasyona \% 1 zeolit katkısının broyler performansı üzerine herhangi bir etkisinin olmadığını belirtmişlerdir. Öztürk ve ark. (1996) 720 adet etlik piliç üzerinde yaptıkları çalışmada \%0, 1, 2 ve 3 zeolit içeren yemlerle piliçleri beslediklerinde çalışma sonunda canlı ağırlık bakımından bir fark bulamamışlardır.

Yem dönüşüm oranı bakımından haftalara göre zeolit uygulamasina tek yönlü varyans analizi uygulandığında (Çizelge 4) tüm haftalarda istatistikî olarak herhangi bir farklılık bulunmamıştır $(\mathrm{P}>0.05)$. 
Çizelge 3. Zeolit uygulamasının haftalara göre canlı ağırlık artışlarına etkileri

\begin{tabular}{|c|c|c|c|c|c|c|c|c|c|}
\hline \multirow{2}{*}{ Zeolit } & Hafta & \multirow{2}{*}{ Zeolit } & Hafta & \multirow{2}{*}{ Zeolit } & Hafta & \multirow{2}{*}{ Zeolit } & Hafta & \multirow{2}{*}{ Zeolit } & Hafta \\
\hline & $1-2$ & & 3 & & 4 & & 5 & & 6 \\
\hline$\% 0,5$ & $396,8^{a} \pm 4,8$ & $\% 0,75$ & $845,8^{a} \pm 13,0$ & $\% 1$ & $1364,7^{\mathrm{ab}} \pm 20,9$ & $\% 1$ & $2038,1^{\mathrm{ab}} \pm 45,0$ & $\% 1,25$ & $2620,0^{a} \pm 45,9$ \\
\hline$\% 1$ & $393^{a} \pm 10,3$ & $\% 1,5$ & $822,2^{a} \pm 8,9$ & $\% 2$ & $1310,3^{\mathrm{b}} \pm 28,0$ & $\% 2$ & $1931,0^{b} \pm 30,3$ & $\% 2,5$ & $2621,0^{a} \pm 18,6$ \\
\hline$\% 0$ & $405,2^{\mathrm{a}} \pm 1,0$ & $\% 0$ & $843,2^{a} \pm 4,8$ & $\% 0$ & $1430,8^{a} \pm 19,7$ & $\% 0$ & $2058,4^{a} \pm 5,4$ & $\% 0$ & $2619,7^{a} \pm 9,8$ \\
\hline
\end{tabular}

Çizelge 4. Zeolit uygulamasının haftalara göre haftalık yem dönüşüm oranlarına etkileri

\begin{tabular}{|c|c|c|c|c|c|c|c|c|c|}
\hline \multirow{3}{*}{ Zeolit } & & \multirow{3}{*}{ Zeolit } & & \multirow{3}{*}{ Zeolit } & & \multirow{3}{*}{ Zeolit } & & \multirow{3}{*}{ Zeolit } & \multirow{3}{*}{$\begin{array}{l}\text { Hafta } \\
6\end{array}$} \\
\hline & Hafta & & Hafta & & Hafta & & Hafta & & \\
\hline & 2 & & 3 & & 4 & & 5 & & \\
\hline$\% 0,5$ & $1,343^{\mathrm{a}} \pm 0,024$ & $\% 0,75$ & $1,487 \mathrm{a} \pm 0,021$ & $\% 1$ & 1,583 a $\pm 0,006$ & $\% 1$ & $1,610^{a} \pm 0,005$ & $\% 1,25$ & $1,663^{a} \pm 0,003$ \\
\hline$\% 1$ & $1,283^{a} \pm 0,038$ & $\% 1,5$ & 1,453 a $\pm 0,017$ & $\% 2$ & $1,557 \mathrm{a} \pm 0,012$ & $\% 2$ & $1,617 \mathrm{a} \pm 0,014$ & $\% 2,5$ & $1,640^{a} \pm 0,005$ \\
\hline$\% 0$ & $1,300^{a} \pm 0,032$ & $\% 0$ & $1,467 \mathrm{a} \pm 0,012$ & $\% 0$ & $1,530^{\mathrm{a}} \pm 0,020$ & $\% 0$ & $1,567^{a} \pm 0,023$ & $\% 0$ & $1,637^{a} \pm 0,008$ \\
\hline
\end{tabular}

Zeoliti çok farklı oranlarda kullanarak araştırma yapan birçok araştırıcı, canlı ağırlıkta olduğu gibi, yem dönüşüm oranında da çok farklı sonuçlar bildirmektedir. $\mathrm{Bu}$ çalışmayı destekler mahiyette, Öztürk ve ark.(1996), 720 adet etlik piliç üzerinde yaptıkları çalışmada \% $0,1,2$ ve 3 zeolit içeren yemlerle piliçleri beslediklerinde çalışma sonunda yem dönüşüm oranları bakımından bir fark bulamamışlardır. Eleroğlu ve ark. (2011) 240 etlik piliç üzerinde yaptıkları bir çalışmada grupların yemlerine sirasiyla \% $0,1,3$ ve 5 oranında doğal klinoptilolit katmışlar ve bu çalışmada etlik piliçlerin yem dönüşüm oranlarında bir farklılık bulunmamıştır. Bozkurt ve ark. (1998) yaptıkları çalışmada etlik civciv yemlerine sirasiyla \% $0,1,1.5$ ve 2 oranında zeolit ilave etmişler ve çalışmanın sonunda \% 1 zeolit katılan grupta yem dönüşüm oranının daha iyi sonuç verdiğini bildirmişlerdir. Fisinin ve ark. (1985) Etlik piliç yemlerine $\% 5$ düzeyinde klinoptilolit ilavesinin yem dönüşüm oranlarında iyileşmeler meydana getirdiğini saptamışlardır.

Hem kontrol hem de deneme gruplarında ölüm oranları eşit çıkmış ve yaşama gücü \%96.67 olarak bulunmuştur.

\section{SONUÇ}

Pek çok kullanım alanı bulunan zeolitlerin etlik piliç yemlerine farklı ve artan oranlarda ilave edilmesi ile canlı ağırlık bakımından 2. 3. ve 6 . haftalarda uygulamalar arasında istatistikî olarak herhangi bir farklılık bulunmamıştır $(\mathrm{P}>0.05)$. 4. Haftada canlı ağırlık bakımından zeolit uygulamaları arasında farklılık ortaya çıkmış, en yüksek ortalama grubunun kontrol (\%0) grubu (1430.76 g). En düşük ortalama grubunun ise $\% 1$ zeolitile başlanan (1310.3 g) ortalama grubu olduğu görülmüştür $(\mathrm{P}<0.05)$. Beşinci (5) haftada ise uygulamalar arasındaki farklılık \%10 düzeyinde bulunarak en yüksek kontrol grubu 2058.4 $\mathrm{g}$ en düşük ise yine $\% 1$ zeolit ile başlanan bu haftada $\% 2$ zeolit verilen grup 1931.0 g olduğu görülmüştür $(\mathrm{P}<0.10)$.
Ticari boyutta kullanımının yapılabilmesi için kesin kanaatler oluşturacak sonuçlar elde edilmesinin gerekliliği vardır. Yapılan çalışmalarda farklı sonuçlar elde edildiği gözlenmiştir. Yapılan bu çalışmada ise bu oran ve yöntem ile etlik piliçlerde herhangi bir olumlu etki bulunamamıştır. Ancak zeolit araştırmalarının farklı hayvan yaşlarında, farklı oranlarda ve farklı metotlarda devam etmesi düşünülebilir.

\section{TEŞEKKÜR}

Bu makale Gülin GÖKCE’nin Yüksek Lisans Tezinden üretilmiştir.

\section{KAYNAKLAR}

Altan Ö, Çabuk M, Bozkurt M, Altan A, Özkan K, Alçiçek A 1998. III. Zeolitin Yumurta Tavuklarının Verimi, Yumurta Kalitesi ile Bazı Tibia ve Kan Parametrelerine Etkisi. Ege Üniversitesi Ziraat Fakültesi Dergisi 35. No: 1-2-3: 25- 32.

Anonim 2016. http://www.gordeszeolite.com (Erişim Tarihi: 1 Kasim 2016).

Ata UH 2003. Antibakteriyel Klinoptilolit. Yüksek Lisans Tezi. İstanbul Teknik Üniversitesi Fen Bilimleri Enstitüsü. İstanbul. 16s.

Balevi T, Coşkun B, Seker E, Kurtoğlu V 1999. Yumurta Tavuğu Rasyonlarma Katılan Zeolitin Verim Performansı Üzerine Etkisi, VI. Poultry YUTAV'99 Uluslararası Tavukçuluk Fuarı ve Konferans1, 3-6: 418-425.

Bayaner A 1999. Çorum İlinde Yumurta Tavukçuluğunun Ekonomik Analizi. Tarımsal Ekonomi Araştırma Enstitüsü, Ankara. 2s.

Bilgin Ö, Koç E 2013. Doğal Zeolitlerin Çevre Kirliliği Kontrolünde Kullanımı. Türk Bilimsel Derlemeler Dergisi 6 (1): 169-174

Bozkurt M, Alçiçek A, Altan Ö 1998. Tavukçulukta Zeolit Kullanımı; Zeolitin Etlik Piliç Performansı Bazı Plazma ve Tibia Özellikleri Üzerine Etkileri. Tarım ve Köy işleri Bakanlığı Tarımsal Araştırma Genel Müdürlüğü, Proje Sonuç Raporu.

Camcı Ö, Sarıca M, Yeter, B 2016. Kanatlı Hayvan Yetiştiriciliği Eğitimi ve Öğretiminde Bazı 
Sorunlar. Ulusal Kümes Hayvanları Kongresi Bildiriler Kitabı. Samsun. 55s.

Demirel R, Şentürk D, Doran İ 2010. Doğal Zeolitlerin Hayvancilıta Kullanım Olanakları. Harran Üniversitesi Ziraat Fakültesi Dergisi, 14(2): 13-20.

Eleroğlu H, Yalçın H 2005. Use of Natural Zeolite Supplemented Litter İncreased Broiler Production. South African J. of Anim. Sci. 35: 90-97.

Eleroğlu H, Yalçın H, Yıldırım A, Aker A 2011. Etlik Piliç Yemine Doğal Zeolit İlavesinin Besi Performansı Üzerine Etkileri, Hayvansal Üretim 52(1): 24-32

Fethiere R, Miles RD, Harms RH 1990. Influence of Synthetic Sodium Aluminosilicate on Laying Hens Fed Different Phosphorus Levels. Poultry Science, 69: 2195-2198.

Fisinin V, Agecv V, Sintserova O, Lenkova T, Kvashali N 1985. Zeolites in Diets for Poultry. Ptitsevodstvo No:9: 25-26. Poultry Abstract. (86)12.

Karelina O 1985. Zeolites of Feeding Broilers. Ptitsevodstvo No: 9, $26(\mathrm{Ru})$ Poultry Abstract. (86) 12. Repruduction International. 34: 1097-1103.

Keshavarz K, Mccormick CC 1991. Effect of Sodiumaluminosilicate Oyster Shell and Their Combinations on Acid-Base Balance and Eggshell Quality. Poultry Sci. 70: 313-325.

Köktürk U 1995. Zeolit Madenciliği ve Çevre Sağlığına Etkileri. Endüstriyel Hammaddeler Sempozyumu. 21-22 Nisan, DEU Ünv., İzmir.

Merabishvili MS, Khachaturijan KK, Solenjishvili TG, Bagiashvili TN, Kharabtisvili G, Belyaeva TI 1980. Natural Zeolites in Agriculture. Proc. Symp. Utilisation of Natural Zeolites in Agriculture, pp 57-67. Sukhumi Al. Krupennikovaed, Metzniereba Publ. House, Tblilisi- Georgia.

Miles RD, Harms RH, Laurent SM 1986. Influence of Sodium Zeolite A (EthacalR) on Laying Hen Performance. Nutr. Rep. Int. ; 34: 1097-1103.

Mol F 2001. Değişik Oranlardaki Pomza-Zeolit Karışımlarının Kimi Fiziksel ve Kimyasal Özellikleri. Yüksek Lisans Tezi. Uludağ Üniversitesi Fen Bilimleri Enstitüsü. Anabilim Dalı, Sayfa sayısı, Bursa.

Nakaue HS, Koelliker JK 1981. Studies with Clinoptilolite in Poultry. 1 Effect of Feding Varying Levels of Clinoptilolite (Zeolite) to Dwarf Single Comb White Leghorn Pullets and Ammonia Production. Poultry Science, 60 (5): 944-949.

Oğuz H, Keçeci T, Birdane YO, Önder F, Kurtoğlu V 2002. Effect of Clinoptilolite on Serum Biochemical and Haematological Characters of Broiler Chickens During Aflatoxicosis, Research in Veterinary Science 2000, doi: 10.1053/rvse.2000.0395, www.idealibrary.com 69: 89-93.

Orhun Ö 1997. Zeolitlerde İyon Değişimi, Anadolu Üniversitesi Yayınları, Eskişehir.
Özaydın S 2005. Doğal Klinoptilolitlerin Türkiye'deki Kullanım Olanakları ve Gördes Klinoptilolitlerinin Isıl Özelliklerinin Belirlenmesi Üzerine Bir Araştırma. Doktora Tezi. Ege Üniversitesi Fen Bilimleri Enstitüsü Güneş Enerjisi Ana Bilim Dalı. İzmir. 165s.

Öztürk E, Sarıca M, Karaçay N 1996. Etlik Piliç Rasyonlarına Zeolit (Clinoptilolite) İlavesinin Besi Performansına ve Karkas Özelliklerine Etkileri. IV. Ulusal Nükleer Tarım ve Hayvancılık Kongresi. Uludağ Üniversitesi. Bursa.

Öztürk E, Erener G, Sarıca M 1998. Influence of Natural Zeolite on Performance of Laying Hens and Egg Quality. Tr. J. of Vet. and Anim. Sci. 22(6): 623628.

Pond WG, Yen JT, Varel VH 1988. Response of Growings Wine to Dietary Copper and Clinoptilolit Supplementation. Nutr. Repor. Inter. 37(4): 795803.

Quarles CL 1985. Zeolits A New İngredient May Cut Needed to Produce Poultry Red Meal, Feedstuffs, 7: 35-36.

Roland DA, Laurent SM Orloff HD 1985. Shell Quality as Influenced by Zeolite with Highion Exchange Capability. Poultry Science. 64: 1177-1187.

Roland DA 1988. Further Studies of Effect of Sodium Aluminosilicates on Egg Shell Quality. Poultry Science. 67: 577-584.

Roland DA Sr, Barnes DG, Laurent SM 1991. Influence of Sodium Aluminosilicate, HydroxySodalite, Carnegicite, Aluminum Sulfate and Aluminum Phosphate on Performance of Commercial leghorns. Poultry Science, 70: 805-811.

SAS (SAS Institute 1994).

Suchy P, E. Strakova, Vecerek V, Krâcmarovâ E 2006. The Effect of a Clinoptilolit-Based Feed Supplement on the Performance of Broiler Chickens. Czech Journal of Animal Science, 51[4], 168-173. ISSN 1212-1819

Şengonca M 1998. Hayvan Yetiştirme İlkeleri. Ege Üniversitesi Ziraat Fakültesi Yayınları. No: 534.316.

Waldroup PW, Spenger GK, Smith NK 1985. Evaluation of Zeolites in The Diet of Broiler Chickens, Poultry Sci., 63: 1833-1836. ISSN: 15253171.

Watkins KL, Vagnoni DB, Southern LL 1989. Effect of Dietary Sodium Zeolite A and Excess Calcium on Growth and Tibia Calcium and Phosphorus Concentration in Uninfected and Eimeria Acervulina Infected Chicks. Poultry Sci. 68: 12361240.

Yalçın S, Ergün A, Çolpan İ, Küçükersan K 1987. Zeolitin Yumurta Tavukları Üzerindeki Etkileri. Lalahan Hayvancılık Araştırma Dergisi. Cilt: 27, 1$4,28-49$. 